Original Contribution

\title{
THE PROBLEM OF INTERFERENCE AND ITS INFLUENCE OF LEARNERS NATIVE LANGUAGE
}

\author{
K. Jafarova* \\ Department of Linguoculturology, Faculty of Education, Azerbaijan University of Languages, \\ Baku, Azerbaijan Republic
}

\begin{abstract}
This scientific article focuses on the problem of first language interference in the process of learning English as a second language. While observing the both process of teaching and learning English as a second language, we notice the influence of native language interference, which can occur in different situations while the students learning English. It is strongly believed that grammatical interference is one of the fundamental difficulties faced by the learners of second languages. Judging by the experience we can assume that problems are mainly caused by the lack of substantial knowledge of lexical and grammatical structures and aspects of the target language. The aim of this article is to analyze grammatical interference in the speech of the Azerbaijani students. The purpose of this study is to investigate phenomena of grammatical interference in the written speech of Azerbaijani students while learning English as a second language.

This study is mainly qualitative. Therefore, the qualitative method was used, in order to find out what kinds of interference phenomena occur in the abstracts, analyze the possible reasons for their occurrence and present some suggestions to avoid the problems discussed. Besides, a quantitative analysis was carried out to interpret the results of the study. The analysis is aimed at providing some guidance for future translations. This study concluded that translations from English language into Azerbaijani language tend to be more objective and/or sometimes lose original meanings attributed in the source text.
\end{abstract}

Key words: interference, grammatical interference, bilingualism, language interaction, source language, target language

\section{INTRODUCTION}

As a teacher, I have found that the contact between a native language and a foreign language may result in many deviations in the latter, such as syntactic/grammatical interference, lexical/semantic interference and others. Such deviations or interference cases are often caused by transfer from the mother tongue (L1) to the foreign language (L2). Transfer may be either positive or negative transfer. Positive transfer facilitates the communication in the target language, whereas negative transfer may lead to error while learning the second language (1). These deviations resulting from the contact of L1 with L2 are commonly discussed in terms of grammatical interference or interference phenomena.

\footnotetext{
*Correspondence to: Kamala Avadır Jafarova, Baku, Azerbaijan Republic, str. V. Aliyev, house 173, Tel.: +994 517333814 (mob.); +994012 4344176 (w) e-mail address:

kamacafarova_adu@mail.ru
}

According to Thorberg (2), there are no bilinguals who have a complete command of two languages and possess the ability to switch from one language to another according to the changes that occur in the speech situation, such as interlocutors, topics etc. On the other hand, Bloomfield (3) argues, using a very narrow definition, that bilinguals have a "native like control of two languages." Diebold (4) argues that bilinguals are actually people who have "contact with different models in a second language" and "the ability to use these in the environment of the native language".

\section{GRAMMATICAL INTERFERENCE AND ITS INFLUENCE OF LEARNERS NATIVE LANGUAGE}

Grammatical Interference occurs when the elements of first language included in using of second language step by step in grammatical of second language, word order, use of articles, pronouns, tense and mood and etc.

In the English language the grammatical category of number is additionally supported 
by the grammatical category of definiteness and indefiniteness presented in the form of articles (5).

While using the English nouns, which differ from the Azerbaijani nouns in number, the articles undergo interference. For example, in the English language the indefinite article [a, (an)] is not used with the noun in plural. With such nouns the definite or zero articles is used. Depending on the absence of grammatical category of definiteness/indefiniteness in the Azerbaijani language, another grammatical interference takes place in the English speech of students. The students who forget that some nouns in the English language (goods -mallar, clothes - paltar, people - adamlar, police polis, stairs - pillakan and etc.) have only plural forms, they use the indefinite article with these nouns: "The company got a new goods" (Şirkat yeni mallar alıb.), "A police has come there in a minute" (Polis oraya bir dəqiqadan sonra galib çıxdr.).

The right use of articles in the examples like "the company", "a minute" tells of a higher level of proficiency in the English language, because the sign of interference here is a simple interference, it is the minimal linguistic unit of the bilingual speech. It reflects the deviation from the norms of the English language on the same level of speech while realizing the particular elements of the system of the language (6).

The study of interference of articles plays a great role in the study of grammatical interference in the speech of students, as the assimilation of articles in the English language usually presents great difficulties for students. The students often omit the Indefinite and Definite articles, for example, in word combinations and sentences like the most interesting, the greatest exporter, in the whole world, the people of Azerbaijan, to be a team leader, to write a thank you letter, the best, to take the first place, the countries of the third world, manager is a very important person, to be a very efficient specialist, the last reason, to learn a foreign language, to find a good job, he got a bad mark, my son is still a pupil, English is an international language, English is a very beautiful language, We need an umbrella stand, Could we have the invoice on Monday? Can we get a five percent discount? Such abundance of grammatical interference in the speech of Azerbaijani students is due to the fact that the articles do not exist in Azerbaijani.

Thus, at various levels of proficiency in the English language the Azerbaijani students differently realize the potentials of interference: typological differences because of the lack of grammatical category of definiteness/indefiniteness and articles cause the regular interference at the initial stages of bilingualism (6).

The students and pupils often experience difficulties with the use of personal and possessive pronouns. For example, the English expression "I like" corresponds to the Azerbaijani word combination "xoşuma galir". Because of differences in grammatical constructions of both languages, we find interference in the speech of students when they use this expression. They say "Me like" and "Me likes" substituting the personal pronoun in the nominative case $I$ for the personal pronoun in the indirect case me which corresponds to the Azerbaijani construction of the expression.

The verb to let and the corresponding personal pronoun in the indirect case are used to express an inducement, for example, "Let him go home" (Qoy o eva getsin.). Under the influence of Azerbaijani where in this sentence the personal pronoun in the nominative case is used, the students often use the corresponding personal pronoun in the nominative case in the English language "Let he go home".

The issue of grammatical category of case in the English language remains debatable; however, the generally accepted view is that the case system of the English noun is presented by two cases: common and possessive (7).

As the English language refers to analytical languages, but Azerbaijani to synthetical ones, then mainly prepositions in the English language perform the function of a link between the words and/or used for the expression of object, adverbial and other relations which in Azerbaijani can be additionally or independently expressed by means of case forms of nouns and pronouns.

In English unlike Azerbaijani, nouns, as well as the pronouns in all the cases have no special endings. That's why, various relations in English are expressed by prepositions and word order in the sentence. Typological differences in the expression of various case relations create potentials for grammatical interference.

The expression of tenses by word order in the English language creates considerable difficulties for the Azerbaijani students. Thus, in the sentence "Who will be able to meet 
tomorrow the delegation at the station?" (Kim sabah nümayəndo heyətini vağzalda qarşllayacaq?) The students do not use the direct object after the verb, but after the adverbial modifier of time which is set at the end or at the beginning of the sentence. The right version is the following: "Who will be able to meet the delegation at the station tomorrow?" (Kim sabah nümayondo heyatini vağzalda qarşllayacaq? or Kim sabah nümayəndə heyətini vă̆zalda qarşılaya bilacak?). Or, for example, the adverbs of the Indefinite Tense always, often, seldom, never, usually that are usually placed before the notional verbs or the verb to be. However, students often place these adverbs at any place in English sentences under the influence of the Azerbaijani language in which such adverbs have no fixed place in the sentence: "What usually do you do in the evening?" instead of "What do you usually do in the evening?", "His lectures always have been interesting" instead of "His lectures have always been interesting", "He said that his parents had always lived in the country".

The expression of spatial meaning of place by word order in the English language causes some difficulties for the Azerbaijani students. This happens while using the English expressions there is/there are to denote the location of the subject or subjects.

The students often omit the expression there is/there are in the affirmative sentence. For example, the students translate the sentence "Bizim manzilimizdo 3 otaq var" as "In our flat 3 rooms" instead of "There are 3 rooms in our flat". Such a word order in English corresponds to the one in Azerbaijani.

While formulating the interrogative sentence with the expression there is/there are, the students often omit them even identifying them in the affirmative sentence. For example, most of the students asked the question "How many windows in the room?" to the sentence "There are three windows in the room", omitting the expression there is/there are, and only three of them asked the right question: "How many windows are there in the room?"

In some cases while formulating the English sentence the students do not omit the expression there is/there are using them not at the beginning but in other places of the sentence, that also breaks the structure of the sentence. For example, the students break the structure of the English sentence in the sentence "Hor kompaniyada işçi iyerarxiyası var" using the expression there is/there are in that place of the sentence where it must not be:
" $A$ hierarchy of employees there is in every company". In such sentences the expression there is/there are must stand at the beginning of the sentence: "There is a hierarchy of employees in every company”.

The students often forget about this expression substituting it with to be and to have in the sentences like "Three windows are in the room" (Otaqda 3 pancara var.), "Our flat has two room” (Manzilimizdo iki otaq var).

The preposition of in English is used to form the genitive case of nouns while expressing the object, subject, attributive relations. However, under the influence of Azerbaijani, in which the endings are used to form the cases, the students always omit the preposition of in their speech. For example, one can come across such cases of deviation from the norm of English: "This form business organization is the most important in Azerbaijan" instead of "This form of business organization is the most important in Azerbaijan", "I live in the town Ganja" instead of "I live in the town of Ganja”, "the success an organization" instead of "the success of an organization", "expansion our company" instead of "expansion of our company", "the advantages this type of organization" instead of "the advantages of this type of organization".

The use of preposition of instead of by to denote the authorship of art work is also one of the typical mistakes encountered in the speech of the students: "They read the books written of English writers" instead of "They read the books written by English writers".

The students have some difficulties in using the preposition to in combination with nouns or pronouns for the expression of object meanings given in Azerbaijani with dative case without preposition. That's why, the students omit this preposition in the sentences like "I showed my summer photos (to) my friends", "When asked I always give my books (to) my friends", "When I have problems my parents always give some good advice (to) me".

The preposition by and with used relatively to express a character or acting forces and the subject, which correspond to the instrumental case of Azerbaijani without preposition always are interfered in the English speech of students. In their statements the students omit these prepositions, for example, in the sentences like "St.Paul Cathedral was designed (by) sir Christopher Wren", "The idea of heating a house (with) fire is useful". 
The expression of various spatial meanings (direction, place, time, manner, cause and effect of action) are always given in the English language with prepositions. For example, the students have difficulties while expressing the meanings of direction or place, for instance, go home (eva getmak) and to be at home (evdo olmaq), as in Azerbaijani the expression evda olmaq is used without preposition, but in English it is used with the preposition at which points to the location in such expressions.

The students in their English speech often omit this preposition under the influence of Azerbaijani, for example, they often say and write to be home. Such deviations from the norm of the English language appear while using the expressions maktabda olmaq, that is, maktabin binasinda olmaq - to be at school, işdo olmaq - to be at work.

The expression of tense by way of prepositions present some difficulties for the Azerbaijani students. So, for example, preposition on, (on Monday, on Friday etc.) is used to denote the event occurred in some day of a week or the date in the English language. However, the students substitute this preposition for the one in that corresponds to the azeri expression Şənbə günӥ, Cümə günü.

To denote the event occurred on some date in the English language the preposition on is also used: on the tenth of December, on the ninth of May (dekabrin onu, mayın doqquzu). In the Azerbaijani language such constructions are used without preposition that leads to the grammatical interference in the English speech of students as they always omit the preposition on or use the other ones, for example, in or at.

"Thus, the wrong use of prepositions is due to the peculiarity of the subjective perception of their meanings by the people speaking different languages. The result of such perception is the use of preposition on the analogy of the native language, as well as the transfer of such use to similar cases of the foreign language" (8).

Some differences in the grammatical categories of Azerbaijani and English adjectives and adverbs, for example, in the formation of the degrees of comparison, are also the potential field for the grammatical interference. In the formation of the degrees of comparison of the English adjectives and adverbs by the Azerbaijani students one can note the examples of the grammatical interference in those cases where the students form the comparative and superlative degrees of the special group of adjectives and adverbs according to the common rules. For example, the students say gooder instead of better (comparative degree from the adjective good), and badder instead of worse (comparative degree from the adjective $b a d$ ). In the other cases the students form the degrees of comparison of adjectives confusing the rules, for example, they say the most great instead of the greatest (superlative degree from great).

\section{CONCLUSION}

Interference can effect on any aspects of language, it can be negative and positive depending on the features of both languages. The greater the differences between the two languages, the more negative the effects of interference are expected to be. Grammatical interference is a very common and normal issue which can be overcome after the careful observation and patient practice. Interference in this case happened because the morphological process in English language, especially in the verb construction. In English, verb does not need the inflectional morphology to make the sentence clear as the Azerbaijani language. As a result, the speakers inclined to use the base form to show the verb in Azerbaijani sentence.

The same time, we consider that language interference is the effect of language learner's first language on his/her production of the language he/she is learning. It means that the speaker's first language influences his/her second or foreign language. Observations and clear understanding of the problem enables us to speak about the differences between acquisition and learning and makes it possible to investigate their interrelationship as well as the implications for the teaching of languages.

\section{REFERENCES}

1. Benson C. The importance of mother tongue-based schooling for educational quality. Background paper prepared for the Education for All Global Monitoring Report 2005. The Quality Imperative. Centre for Research on Bilingualism Stockholm University, 2004.

2. Thorberg, Y. English in a multilingual society. A study of interference phenomena in east African English with special reference to the language learning situation. Stockholm University, 1970.

3. Bloomfield L. Language. New York. Henry Holt, 1933.

4. Diebold A. Incipient bilingualism. Vrije Universiteit Brussel. Honiton, Devon, 1961. 
5. Koshevaya I.G. The course of English Russian comparative typology. Text.: teaching guide/I.G.Koshevaya. M.: Vysshaya shkola, 2008.

6. Khashimov R.I. Transposition and interference in the Russian speech of nonRussians (lexical and semantic level)/ R.I.Khashimov // European languages:

historiography, theory, history. Interuniversity collection of scientific works. Yelets, 4th edition, 2003.
7. Blokh M.Y. Theoretical English Grammar (in English). Text.: $3^{\text {rd }}$ edition, revised / M.Y.Blokh. Moscow: Vysshaya shkola, 2000.

8. Budrenyuk G.M., Grigorevskiy V.M. Linguistic interference and way of its identification. - Chisinau: Shtiinta, 1978. 